\title{
EVALUATION OF GAS-REBURNING AND LOW NO BURNERS ON A WALL FIRED BOILER
}

\section{$D E-F C 22-91 P C 90547$}

Technical Progress Report No. 19

For the Period

April 1 through June 30, 1995

Prepared for

U.S. Department of Energy

Gas Research Institute

Public Service Company of Colorado

Colorado Interstate Gas Company

Electric Power Research Institute

Prepared by

Energy and Environmental Research Corporation

18 Mason

Irvine, California 92718

August 11, 1995 
TABLE OF CONTENTS

LEGAL NOTICE $\ldots \ldots \ldots \ldots \ldots \ldots \ldots \ldots \ldots$ ii

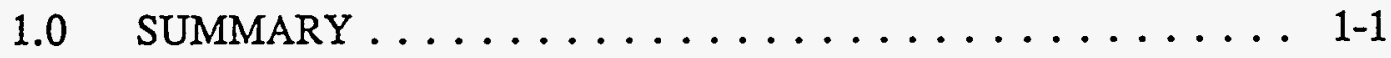

2.0 INTRODUCTION $\ldots \ldots \ldots \ldots \ldots \ldots \ldots \ldots \ldots \ldots$

3.0 PROJECT DESCRIPTION . . . . . . . . . . 3-1

4.0 PROJECT STATUS $\ldots \ldots \ldots \ldots \ldots \ldots \ldots \ldots \ldots$. . . .

4.1 Phase I Design \& Permitting . . . . . . . . . 4-1

4.2 Phase II Construction \& Startup . . . . . . . . . 4 4-1

4.3 Phase III Operation, Data Collection, $\ldots \ldots \ldots \ldots \ldots$.

5.0 PLANNED ACTIVITIES $\ldots \ldots \ldots \ldots \ldots \ldots \ldots \ldots$ 5-1

6.0 REPORT DISTRIBUTION LIST $\ldots \ldots \ldots \ldots \ldots \ldots$. . . . . . 


\section{LEGAL NOTICE}

This report was prepared by Energy and Environmental Research Corporation (EER) as an account of work sponsored by the Gas Research Institute (GRI), the United States Department of Energy (DOE), Colorado Interstate Gas Company (CIG), and the Electric Power Research Institute (EPRI). Neither, GRI, DOE, CIG, EPRI, nor members of GRI, DOE, CIG, EPRI nor any person acting on their behalf;

a. Makes any warranty or representation, express or implied with respect to the accuracy, completeness, or usefulness of the information contained in this report, or that the use of any information, apparatus, method, or process disclosed in this report may not infringe privately-owned rights, or

b. Assumes any liability with respect to the use of, or for damages resulting from the use of, any information, apparatus, method, or process disclosed in this report. 
Clean Coal Technology (CCT) implies the use of coal in an environmentally acceptable manner. Coal combustion results in the emission of oxides of nitrogen $\left(\mathrm{NO}_{x}\right)$, which are precursors of both acid rain and ozone formation. The primary objective of this CCT project is to evaluate the use of Gas Reburning and Low $\mathrm{NO}_{\mathrm{x}}$ Burners (GR-LNB) for $\mathrm{NO}_{\mathrm{x}}$ emission control from a wall fired boiler. It is anticipated that, if the demonstration is successful, the GR-LNB technology could become commercialized during the 1990's and will be capable of (1) achieving significant reduction in the emissions of nitrogen oxides and sulfur dioxide (another acid rain precursor) from existing facilities to minimize environmental impacts such as transboundary and interstate pollution and/or (2) providing for future energy needs in an environmentally acceptable manner.

Low $\mathrm{NO}_{\mathrm{x}}$ burners are designed to delay the mixing of the coal fuel with combustion air to minimize the $\mathrm{NO}_{\mathrm{x}}$ formation. Typically, one may obtain up to $50 \%$ reduction in $\mathrm{NO}_{\mathrm{x}}$ emissions through the use of LNB. For LNB applications, the technology is developed and a number of LNB designs are commercially available.

With GR, about 80-85 percent of the coal fuel is fired in the main combustion zone. The balance of the fuel is added downstream as natural gas to create a slightly fuel rich environment in which $\mathrm{NO}_{x}$ is converted to $\mathrm{N}_{2}$. The combustion process is completed by over-fire air addition. $\mathrm{SO}_{\mathrm{x}}$ emissions are reduced to the extent that natural gas replaces sulfur-containing coal. The level of $\mathrm{NO}_{x}$ reduction achievable with $15-20 \%$ natural gas is on the order of 50 $60 \%$. Thus the emission reduction target of the combination of these two developed technologies is about $70 \%$.

Specifically, the technical objectives of this project are to:

1. Demonstrate the full effectiveness of GR-LNB for $\mathrm{NO}_{\mathrm{x}}$ emission control. This includes the performance of the separate technologies and of the integrated GRLNB technology. 
2. Demonstrate the compatibility of GR-LNB with existing wall fired boilers.

3. Demonstrate the additional reductions in $\mathrm{SO}_{2}$, particulate and $\mathrm{CO}_{2}$ achievable with GR-LNB.

4. Demonstrate the synergism of GR-LNB with sorbent injection for $\mathrm{SO}_{2}$ control if a sorbent injection system is installed outside the scope of this project.

5. Develop a data base which can be used to establish the commercial viability of GR-LNB to meet existing and projected emission control regulations.

6. Transfer the project results to industry to ensure that GR-LNB is a recognized cost effective competitor for utility boiler emission control.

This project is being conducted in three phases at the host site, a $172 \mathrm{MW}_{\mathrm{c}}$ wall fired boiler of Public Service Company of Colorado (PSCo), Cherokee Unit 3 in Denver, Colorado: Phase I - Design and Permitting, Phase II - Construction and Start-up, and Phase III - Operation, Data Collection, Reporting and Disposition. Technology transfer to industry is accomplished through the formation of an industry panel.

Phase I of the project commenced on October 13, 1990 and was completed June 30, 1992.

Phase II of the project commenced on June 13, 1991, and was completed on September 2, 1992.

Phase III of the project was approved and commenced on April 15, 1992. Phase III activities during this reporting period involved completion of the second generation gas reburning parametric testing. This technology utilizes enhanced natural gas and overfire air injectors with elimination of the flue gas recirculation system. The objective is to demonstrate $\mathrm{NO}_{\mathbf{x}}$ reductions similar to that of long term testing but with a reduced capital cost requirement through elimination of the FGR system. 
Long term testing of the equipment demonstrated an average $\mathrm{NO}_{\mathrm{x}}$ reduction of $65 \%$ using $18 \%$ gas heat input. After removing the flue gas recirculation system (Second Generation GR), an average $\mathrm{NO}_{x}$ of $64 \%$ was achieved using $13 \%$ gas heat input. The project goal of $70 \%$ reduction was achieved, but not on an average basis due to the load requirements of the utility. $\mathrm{NO}_{x}$ was reduced with burners alone an average of $37 \%$. No detrimental boiler impacts resulting from GR-LNB were observed. 
Key Words

$\mathrm{SO}_{x}$

$\mathrm{SO}_{2}$

$\mathrm{NO}_{x}$

NO

Burners

Start-up

CEMS

Reburning

BPMS
Ash

Coal

Gas

Low $\mathrm{NO}_{x}$ Burners

Construction

Instrumentation

Industry Panel

Injection
Emission

Control

Boiler

Precipitator

Flue Gas

Contracts

Baghouse

Ducts 
The specific goal of this project is to demonstrate $\mathrm{NO}_{\mathrm{x}}$ emission reductions of 70 percent or more as a result of combining LNB and GR on a utility boiler having the design characteristics mentioned above. A Host Site Agreement has been signed by EER and a utility company in the State of Colorado: Public Service Company of Colorado (Cherokee Unit No. 3, $172 \mathrm{MW}_{\mathrm{e}}$ ) front wall fired boiler near Denver.

To achieve the objectives of the project, it is being conducted in the following three phases at the host site.

Phase I: $\quad$ Design and Permitting

Phase II: Construction and Start-up

Phase III: Operation, Data Collection, Reporting and Disposition

Phase I is complete.

Phase II is complete.

Phase III of the project (Operation, Data Collection, Reporting and Disposition) officially began on April 15, 1992 with Task 1, Project Management work. Due to delays such as the rebuilding of pulverizers, Task 2, Optimization commenced mid-September, 1992. Planned and unplanned boiler shutdowns delayed completion of Task 2 until late April 1993. Task 3, Long Term Testing began on April 27, 1993 with Gas Reburning controls configured in automatic to provide a load following test condition. Long term testing continued through January 20, 1994. The six week Cherokee Unit \#3 outage followed, concluding on March 6, 1994. After completion of the outage, during which EER made a number of enhancements to the Gas Reburning (GR) system, the Low $\mathrm{NO}_{x}$ Burners were started up and optimized. Guarantee tests followed. During the last quarter, testing of the Second Generation Gas Reburning System was completed. 
Major work performed during this past quarter was as follows:

1. The workscope for restoration was completed. Solicitation of subcontractors for restoration activities is in progress.

2. Compilation, analysis and assembly of the final report continues. The environmental reports were completed and submitted. 
Within the final phase of the project, the following tasks will be performed to demonstrate the cost effective control of $\mathrm{NO}_{\mathrm{x}}$ and $\mathrm{SO}_{\mathrm{x}}$ emissions from pre-NSPS coal fired utility boilers:

\section{Phase III: OPERATION, DATA COLLECTION, REPORTING AND DISPOSITION}

\section{Task 1 - Project Management}

- Continuation of Phases I and II project management activities.

- Conducting final project review at conclusion of project.

Task 2 - Optimization Testing

- Optimization of LNB installation.

- Optimization of GR-LNB technology

- Evaluation of effects of process variables on emission control performance.

- Determination of operating conditions for optimum overall performance.

\section{Task 3 - Long Term Tests}

- Operation of GR-LNB equipment under optimized conditions for approximately one-year duration.

- Measurement of emission control system performance.

- Determination of boiler impacts.

Task 4 - Evaluation of Field Test Results

- Analysis of test data. 
- Preparation of guideline manuals for application of GR-LNB technology, including design recommendations, cost projection and comparisons with competing technologies.

\section{Task 5 - Restoration}

- Disposition of GR-LNB equipment installation:

To be retained by host site or removal and restoration work.

Task 6 - Technology Transfer

- Continuation of technology transfer activities from Phases I and II.

- Meeting with Industry Panel to review results obtained.

Task 7 - Gas Reburning Enhancements

- Modification of OFA and Natural Gas injectors.

- Elimination of FGR system.

- Parametric and Long Term Testing of GR Enhancements. 
4.1 Phase I Design and Permitting Phase I is Complete.

4.2 Phase II Construction and Startup Phase II is Complete.

4.3 Phase III Operation, Data Collection, Reporting and Disposition Reports are in progress.

\subsubsection{Task 1 - Project Management}

Project management activities this reporting period consisted of coordinating and planning, data analysis and issuance of reports as required by the cooperative agreement.

\subsubsection{Task 2 - Optimization Testing}

Optimization testing is completed.

\subsubsection{Task 3 - Long Term Testing}

Long term testing is completed. 


\subsubsection{Task 4 - Evaluation of Results}

Testing of the Second Generation Gas Reburning System was completed on January 26, 1995. The results show that the re-design of the natural gas injectors plus removal of the flue gas recirculation system resulted in virtually the same $\mathrm{NO}_{\mathrm{x}}$ reduction as found before the modification, while using a lower gas heat input. The re-design of the overfire air nozzles resulted in a reduced level of $\mathrm{CO}$ emissions.

\subsubsection{Restoration}

PSCo will retain the gas reburning and overfire air portions of the system, but require restoration of the flue gas recirculation system.

\subsubsection{Technology Transfer}

The final industry panel meeting has been scheduled for October 18-19, 1995 in Philadelphia. The event will begin with a Participants-only meeting on the morning of the 18th. During this session, EER will present a summary of the CCT Project results and discuss marketing strategies for the Project technologies. .

The Industry Panel/Workshop will begin on the afternoon of the 18th and conclude at mid-afternoon of the 19th. The focus of the Workshop is reburning and its role in developing cost effective $\mathrm{NO}_{\mathrm{x}}$ compliance strategies. The meeting will be conducted as an informal affair with presentations by EER and selected utilities plus round-table discussions focusing on specific applications to meet Clean Air Act $\mathrm{NO}_{x}$ requirements.

EER is focusing its solicitation for this Workshop on the utilities in the Northeast U.S., due to their imminent requirement to meet $\mathrm{NO}_{x}$ reduction limits (refer to Ozone Transport Commission Memorandum of Understanding) and due to the high use of oil as the primary fuel (cost competitive with natural gas). During the past reporting period, these utilities have been 
phoned to determine the appropriate contact names and assess their interest in attending the Workshop. Preliminary indications have been very positive.

A technical paper has been prepared to present the results of the GR-LNB project at the Fourth Annual Clean Technology Conference to be held in Denver in September, 1995.

\subsubsection{Gas Reburning Enhancements}

Parametric/optimization testing of the second generation gas reburning was completed in January, 1995. 
During the next quarter (October through December, 1994) the following work is planned:

1. Project Management continues into the next quarter

2. Continue with final reports.

3. Select a subcontractor for restoration. 
The number in parentheses 0 indicates the total number of copies submitted.

\subsection{Funding Organization Distribution}

\subsubsection{U.S. Department of Energy}

Mr. Harry J. Ritz (2)

PETC Technical Project Manager

Mail Stop 920-L

U.S. Department of Energy/PETC

P.O. Box 10940

Pittsburgh, PA 15236

Mr. John Augustine (1)

Contracting Specialist

AD-21, Mail Stop 921-165

U.S. Department of Energy/PETC

P.O. Box 10940

Pittsburgh, PA 15236

Dr. C. Lowell Miller (1)

Associate Deputy for Clean Coal

Office of Clean Coal Technology

FE-24, C-178

U.S. Department of Energy

Washington, DC 20545

Mr. Paul A. Gottlieb (1)

Office of Patent Counsel

U.S. Department of Energy

9800 South Cass Avenue

Argonne, IL 60439

Office of Technology Transfer (3)

Mail Stop 58-MEZZ

U.S. Department of Energy/PETC

P.O. Box 10940

Pittsburgh, PA 15236 
Dr. S.N. Roger Rao (1)

Burns and Roe Technical Group Manager

P.O. Box 18288

Pittsburgh, PA 15236

Mr. Douglas Uthus (1)

HQ DOE Program Manager

FE-22, 3E-042, Forrestal

U.S. Department of Energy

Washington, D.C. 20585

\subsubsection{Gas Research Institute}

Mr. Paul Bautista (2)

Gas Research Institute

8600 W. Bryn Mawr Ave.

Chicago, Illinois 60631

\subsubsection{Colorado Interstate Gas Company}

Mr. R. Patrick Cummins (2)

Manager, Planning Evaluation

Colorado Interstate Gas Company

P.O. Box 1087

Colorado Springs, Colorado 80944

\subsubsection{Electric Power Research Institute}

Mr. Tony Facchiano (2)

Electric Power Research Institute

3412 Hillview Avenue

Palo Alto, California 94303 


\subsection{Host Utility Distribution}

Mr. Charles Bomberger (6)

Production Services Manager

Public Service Company of Colorado

5900 East 39th Avenue

Denver, Colorado 80207 